\title{
An Investigation of the Impact of Food Aid on Food Crop Production in Zimbabwe
}

\section{Calvin Mudzingiri}

\author{
University of the Free State-Qwaqwa Campus, Department of Economics, Bag X13, Phuthaditjhaba, 9866, South Africa
}

Email:mudzingiric@qwa.ufs.ac.za

Clainos Chidoko

Great Zimbabwe University, Department of Economics, Zimbabwe

Email: cchidoko@yahoo.co.uk

\section{Doi:10.5901/mjss.2014.v5n27p77}

\begin{abstract}
The impact of food aid on food crop production has been subject to debate for a long time in literature. A couple of studies suggest that food aid has a disincentive effect on food crops production. This study uses an autoregressive distributed model to investigate whether there are effects of food aid on maize crop production in Zimbabwe from 1980-2007. The study focuses on two agricultural sectors, namely; commercial and communal agricultural sectors. Food aid shipments significantly affect maize crop production in the commercial agricultural sector. We find no evidence of the impact of food aid on food production in the communal agricultural sector. The study recommends that trade of food crops should remain liberalized to ensure that producers realize a return that is in line with world market price.
\end{abstract}

Keywords: Food Aid, Food Production, Impact of Food Aid, Economic Development

\section{Introduction}

In the recent years, the Sub Saharan Africa, Zimbabwe included, has been characterized by food shortages and a rise in the flow of food aid (Abdulai et al., 2005). Although food aid has been known to improve welfare of consumers, a lot of questions have been raised on the effect on local producers of food crops. Zimbabwe experienced a decline in maize output in the two major agricultural sectors, namely; commercial and communal. The fact that maize is the staple food consumed by more than $90 \%$ of the population in the country is a cause for concern. Existing literature identifies many factors behind the free fall of maize production; fast track land reform, lack of inputs, poor producer prices, poor farming methods and natural disasters such as drought (Chaumba et al., 2003; Moyo, 2000; Palmer, 1990; Sachikonye, 2003). The purpose of this study is to establish whether food aid receipts affect maize crop production in Zimbabwe.

Zimbabwe has received a substantial amount of food aid since 1980. Statistics from the World Food Program (WFP) and Ministry of Social Welfare reflect that the country received sizable quantities of food aid during 1979-1982, 1990-1992, 1995-1997, and from 2001 to 2008. The trend from 2001 to 2007 is portraying an over reliance on food aid hence it is imperative to explore whether food aid has an effect on food crop production since continued shipment of food into a country signifies poor crop output (Tadesse and Shively, 2009).

Zimbabwe is known to be a net exporter of maize in Southern Africa in the 1980s and 1990s (Sachikonye, 2003). Of great concern is the sudden decrease in maize output resulting in the country being a net importer of maize. Aside the impact of land reform, poor producer prices, adverse climatic conditions, mismanagement of grain reserves and lack of inputs, nothing has been investigated in the area of the effect food aid on maize production. In Zimbabwe various kinds of food aid have been provided since 1980, which include targeted and program food aid. Considering this background, it is important to understand the impact of food aid on maize production in Zimbabwe since it is the staple food consumed by over $90 \%$ of the citizens (The Agriculture Sector of Zimbabwe Statistical Bulletin, 2008). .

Given the significance of reversing maize output decline in Zimbabwe and the contested assessments of the role that food aid plays in agricultural development, it is of paramount importance to investigate whether food aid has a disincentive or incentive effect on food crop production (Barrett, 2006; Isenman and Singer, 1977; Tadesse and Shively, 2009). Zimbabwe, like any developing country, would like to develop her agricultural sector to levels that ensure food security and a move from food handouts dependency. The rationale of the study is to investigate whether food aid affects food crop production. The study reveals that food aid significantly affected maize production in the commercial farming 
sector. Flows of food aid in Zimbabwe tend to reduce maize production, which is a food crop in the commercial farming sector. Other issues that this study would want to put into perspective are ways that would ensure self sufficiency in food crop production.

The next section profiles the literature review, section 3 details the methodology, Section 4 focuses on data interpretation and analysis, while Section 5 looks at conclusions and recommendations.

\section{Theory and Empirical Studies}

\subsection{Food aid, Economic Development and Food Crop Production}

The literature on food and food crop production is inconclusive. Those who speak for food aid distribution suggest that it reverse adverse conditions in the recipient country (Barrett and Maxwell, 2006; Bezuneh et al., 2003). Some of the benefits that may accrue to the recipient country are that, food aid can further economic development through adding resources that can be used in current consumption and accumulation. Food is also traded on the international market which entails food aid can provide balance of payment support, just like any form of foreign aid by reducing the foreign currency spent on food imports. More so, food aid augments the domestic availability of food, especially if it is targeted to the poor. Donations to the vulnerable society alleviate poverty which is a prerequisite for economic development. Furthermore, food aid improves the health and nutritional status of the poor. It augments their human capital and future income earning capability. In addition, food aid tied to development-oriented projects that would not have been undertaken will promote development (Srinivasan, 1989).

Food aid can be defined in two broad types mainly program food aid and targeted food aid. These two categories of food aid impact differently on food crop production. Program food aid is usually provided even in times of good harvest in the recipient country. The recipient country will sell food aid in the economy and use the proceeds to fund some developmental programs. In this case, food aid helps in improving the balance of payment as it acts as some foreign grant to the government. If program food aid is sold in an open market economy in the recipient economy, it has negative and detrimental effects on production of food crop by farmers (Barrett, 2001).

Excess supply of food in an economy caused by food aid receipts may result in prices of food crop falling below world market price. This diminishes return from food crop sales by farmers leading to disincentive effect in the recipient country (Barrett, 2002; Bezuneh and Deaton, 1997; Lavy, 1990; Tadesse and Shively, 2009). To avert the disincentive effect, government can make use of tariffs and subsidies. Tariffs ensure that the price on donated food aid becomes higher than locally produced food crop resulting in consumers demanding more of what is produced in the domestic economy. This is not always feasible as people who receive food aid are poor and may not afford to buy food. Subsidies, although they are an expense to the government, ensure a reduced cost of production by local farmers. Low cost of production ensures increased marginal profit that act as an incentive to the farmers to continue producing increased output.

Targeted food aid is usually provided when a country is facing food crisis. The crisis could be due to manmade or natural disaster. This type of food aid is effective when it is provided to the needy people than when provided to the less needy people. The less needy may end up selling food aid in the open market, resulting in excess supply in the domestic market, dampening prices of food crop produce and by so doing acting in a disincentive manner (Barrett, 1998; Clay et al., 1999). Targeted food aid constituted the biggest chunk of food aid provided by donor countries to Zimbabwe for the period under study. In the same vein, Zimbabwe food aid shipments were at the peak when there was food crisis, for example, in the year 1992 and 2003. Targeted food aid can result in an increase in food crop output if provided to the needy, since this avails food to farmers and improve their nutritional standards. Well nourished farmers have the energy and strengths to produce an increased output.

\subsection{Agricultural Farming Sectors in Zimbabwe: An Overview}

There are two agricultural sectors in Zimbabwe namely; Commercial and Communal agricultural sectors. Communal farmers carry out their agricultural activities on an area that is 30 hectares or less of land. On the other hand, commercial farmers have large tracts of land that are above 30 hectares (Muchapondwa, 2008). Communal farmers in Zimbabwe have much of their attributes similar to those that define a peasant farmer. Majority of food aid recipients are communal farmers. They are faced with a wide range of uncertainties in crop production. In Zimbabwe communal farmers produced on average over $60 \%$ of total national maize production during the period from 1980 to 2007. The remainder has been known to be produced by commercial farmers (Moyo, 2011) 
Ellis (1992) noted that peasant farmers are risk averse such that they would want to use minimum input-mixes so as to reduce the risk on output. In this regard, reducing input level in a good season results in farmers reaping suboptimal quantities. This perpetuates low levels of output leading to continued survival on food handouts. Furthermore, communal farmers in Zimbabwe rely heavily on family labour and the livelihood is heavily inclined on land cultivation as revealed by the Chayanov and other classical household models (Ellis, 1992). They produce food for consumption and would sell the excess to acquire manufactured goods.

Compounding to farmers' problems is the weather pattern in Zimbabwe, which is unpredictable. The climate is characterized by dry spells, poorly distributed rainfall and floods. Persistent adverse climatic conditions have resulted in a huge number of communal farmers surviving on food aid. In addition, the markets in the developing countries are unstable and are riddled with market imperfections. The farmers are generally poor and in most cases, fail to adopt new technology. There is a high level of poverty and in most cases farmers fail to acquire the necessary inputs for effective production (Levinsohn and McMillan, 2007). It is this exposure to poverty that has seen the majority of communal farmers tending to rely on food aid handouts donated by the Non-Governmental Organizations (NGOs) in Zimbabwe.

Peasant farmers in developing countries are often very poor and households are worried about food insecurity. The rural communities are riddled by incomplete markets and uneven development of infrastructure, which may act as a hindrance to movement of both information and goods. Poor infrastructure has an effect on unavailability of markets for food crop producers resulting in farmers scaling down production leading to food shortages (Ellis, 1992). During times of high output, a lot of commodities are wasted due to poor storage and marketing channels resulting in post-harvest losses leading to food insecurity. Moreover, there general absence of modern technology may influence continued dependency on food aid in Zimbabwe.

The general problems faced by communal sector farmers are also widespread in commercial farming sector. Commercial farmers are profit driven, they produce generally for sale and most of the crops they produce are cash crops. Although commercial farmers are generally better informed than communal farmers in Zimbabwe, the level technology they have is not advanced and is susceptible to poor weather. Climatic conditions that are not favorable for crop production cannot be easily prevented by farmers in Zimbabwe mainly due to poor technology (Chaumba et al., 2003).

Zimbabwe has been one of the few countries in Sub Saharan Africa known for exporting maize grain (Hoogeveen and Kinsey, 2001; Moyo, 2000; Palmer, 1990; Sachikonye, 2003). The period from 1999 to 2008 has seen the economy being the net importer of grain. The decline in total maize output production trend from 2000 to 2007 has mainly been attributed to land reform, poor producer prices, adverse climatic condition and poor technology among other things. Although some of the factors assumed to have contributed to maize output decline can be traced, no investigation has been carried out on the effect of continued reliance on food aid by the economy during the period under study.

\section{Materials and Methods}

\subsection{Model Specification}

The model is based on classical economists' production function (Ghatak, 2003)

$Q_{t}=B W_{t}^{\vartheta} K_{t}^{\alpha} L_{t}^{\gamma}$

$W_{t}$ Stands for other factors that influence maize production in the model

$W_{t}=f\left(R_{t}, A_{t}, P_{t}, F A_{t}\right)$

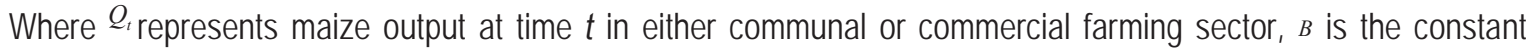

parameter, $R_{t}$ is the average annual rainfall received in Zimbabwe, ${ }^{A_{t}}$ stands for area under maize production, $P_{t}$ signify producer prices of maize, $F A_{t}$ symbolises food aid shipments into Zimbabwe, ${ }^{L_{t}}$ correspond to labour in the agricultural sector, ${ }^{K_{t}}$ stands for capital in the agricultural sector (government budget vote on agriculture) and $\varepsilon_{t}$ is the random disturbance term.

The variables $Q_{t}$ and ${ }^{A_{t}}$ are going to be analyzed for specific sector as PCE (output for maize in the commercial sector), PMN (output for maize in the communal sector), APCE (area under maize cultivation in the commercial sector) and $A P M N$ (area under maize cultivation in the communal sector)

The production function can be specified further as

$Q_{t}=B R_{t}^{\chi} A_{t}^{\delta} P_{t}^{\varepsilon}(F A)_{t}^{\phi} K_{t}^{\alpha} L_{t}^{\gamma}$

A production function should also include prices of substitutes. However, this study made an oversight of prices of 
substitutes, having considered that food aid is usually provided freely to recipients and in situations where it is sold, recorded figures are not available. The general model in linear form appears as follows (Ghatak, 2003).

$$
Q_{t}=B+\chi R_{t}+\delta A_{t}+\imath P_{t}+\varphi F A_{t}+\chi_{t}+\alpha K_{t}+\varepsilon_{t}
$$

Maize production in Zimbabwe $\left(Q_{t}\right)$, the dependent variable is split into two variables namely, maize production in the commercial sector $(P C E)$ and communal sector $(P M N)$. The two variables show maize outputs that were produced in the two agricultural sectors from 1980-2007. Food Aid ( $\left.F_{4}\right)$ statistics were collected mainly from World Food Program offices in Zimbabwe and Ministry of Labour and Social welfare. This variable shows estimates food shipments that were receive in Zimbabwe during the period under study. The research uses food aid estimates for the period under study.

Rainfall $\left(R_{t}\right)$ is a proxy for climatic conditions that prevailed in a particular production year is average annual rainfall $(R)$. Rainfall is an essential component in crop production in Zimbabwe since most farming activities are rain fed (Moyo, 2000).Maize Producer Prices $\left(P_{t}\right)$ act as signals for farmers to produce a certain quantity of output assuming production is profit driven (Snowdon and Vane, 2005). In Zimbabwe, maize producer prices were set by the government through the Ministry of Agriculture. During the period under study, the Grain Marketing Board was the sole buyer as well as exporter of maize and it practices pan-territorial pricing, that is, same price for all maize producers across the country. Considering that the analysis mimics a production model, prices form the integral of incentives.

Labour $^{\left(L_{t}\right)}$ is a vital input that augments capital in the production process. The proxy for labour in agriculture is population in the rural and commercial farming areas. The underlying assumption is that people in rural and commercial farming areas survive on agriculture in one way or another. More so, people in rural areas that are close to commercial farms provide labour in both the communal and commercial agricultural sectors. Capital $\left(K_{t}\right)$ which is government expenditure estimates has been used as proxy for capital in the agricultural sector. The statistics are a reliable stand-in for capital in agriculture as government expenditure in the agricultural sector has a direct and indirect effect in both the commercial and communal agricultural sectors. During the period under study the government of Zimbabwe has actively initiated agricultural production funding programs such as input scheme namely maguta, Zunde Rambo, contract farming among others (Dhemba et al., 2002; Morduch and Sharma, 2002). The variable is split into two data sets, namely area under maize crop production in the commercial $(A P C E)$ and Communal $(A P M N)$ agricultural sectors. The variable is a proxy for land as a factor of production. We collapsed the production model into an Autoregressive Distributed Lag as a way to investigate the effect on production given a lag in the flow of food aid. A conditional Vector Error Correction Model (VECM) or simply an Unrestricted Error Correction Model (UECM) is formulated as given below (Pesaran et al, 2001).

$$
\begin{aligned}
& \Delta Q_{t}=\alpha_{0}+\alpha_{1} Q_{t-1}+\alpha_{2} F A_{t-1}+\alpha_{3} L_{t-1}+\alpha_{4} R_{t-1}+\alpha_{5} P_{t-1}+\alpha_{6} A_{t-1}+\alpha_{7} K_{t-1}+\sum_{j=1}^{n} \phi \Delta Q_{t-j}+\sum_{j=1}^{n} \varphi \Delta F A_{t-j}+ \\
& \sum_{j=1}^{n} \nu \Delta L_{t-j}+\sum_{j=1}^{n} \eta \Delta R_{t-j}+\sum_{j=1}^{n} \kappa \Delta P_{t-j}+\sum_{j=1}^{n} \lambda \Delta A_{t-j}+\sum_{j-1}^{n} \mu \Delta K_{t-j}+\varepsilon_{t}
\end{aligned}
$$

The model is an Autoregressive Distributed Lag (ARDL) which also investigated the effect of previous factors of production on current food crop production.

The major source of the data used in this study is the Agricultural Statistics Bulletin (2008) from the Ministry of Agriculture (Government of Zimbabwe) except capital, food aid and labour. Food aid statistics were collected from the World Food Program and part of the data were collected from the Social Welfare Department in the Ministry of Labour and Social Welfare of the Government of Zimbabwe. Statistics on labour in the Agricultural sector were collected from the Central Statistics Department (Central Statistics Office bulletin 1984, 1994, 2004). Capital represented by Government of Zimbabwe expenditure estimates in the Ministry of Agriculture were collected from The Reserve Bank of Zimbabwe Library.

\section{Results and Interpretation}

This section analyses the data sets from commercial and communal maize production agricultural sectors. It looks descriptive statistics first, followed by testing for stationarity of the variables under examination. Testing for unique cointegrating vector in the data sets is carried out before analyzing the Unrestricted Error Correction model (UECM) by sector. The long-run interaction of variables in the ARDL to co-integration approach models is considered prior to examining the short run dynamics of variables for each sector. We highlight findings at each stage and suggest possible influences. 


\subsection{Descriptive Statistics}

Descriptive Statistics

\begin{tabular}{|l|c|c|c|c|c|c|c|c|c|}
\hline & $P C E$ & $P M N$ & $F A$ & $R$ & $A P C E$ & $A P M N$ & $P$ & $K$ & $L$ \\
\hline Mean & 657759 & 990869 & 65815.2 & 676. & 182216 & 1145813 & 271671 & 18626699 & 7054833 \\
\hline Maximum & 1833400 & 1687000 & 396229 & 989 & 363400 & 1659424 & 4200000 & 106299881 & 8117681 \\
\hline Minimum & 78062 & 115200 & 117 & 335 & 55683 & 627700 & 85 & 18262 & 5239393 \\
\hline Std dev & 395567 & 423373 & 100858 & 180 & 73004 & 235301 & 887844 & 229893563 & 863854.9 \\
\hline Skew ness probability & 0.080 & 0.478 & 0.001 & 0.730 & 0.271 & 0.513 & 0.000 & 0.318 & 0.064 \\
\hline Kurtosis probability & 0.114 & 0.449 & 0.017 & 0.174 & 0.478 & 0.345 & 0.000 & 0.439 & 0.506 \\
\hline
\end{tabular}

The highest quantity of food aid ever shipped in Zimbabwe is 396229 metric tons. On the other hand, the lowest figures recorded for rainfall, communal maize production and commercial maize production in the period under study are 335 mm, 115200 metric tons and 78062 metric tons respectively.

\subsection{Unit Root Tests}

We use the Phillips-Perron (P-P) test for the unit root test. The stationarity test is first tested for data in levels and only those variables that are non-stationary in levels are differenced and tested for the presence of unit root (Brüderl, 2003; Dickey and Fuller, 1981; Enders, 2008).

Unit root test in levels

\begin{tabular}{|c|c|c|}
\hline Variable & t-PP test & Conclusion \\
\hline PCE & -2.10 & Non-stationary \\
\hline PMN & -2.01 & Non-stationary \\
\hline K & $-4.56^{\star \star \star}$ & Stationary \\
\hline FA & -2.41 & Non-stationary \\
\hline R & $-4.27^{\star \star}$ & Stationary \\
\hline P & $-4.77^{\star \star}$ & Stationary \\
\hline APCE & -0.71 & Non-stationary \\
\hline APMN & $-3.65^{\star \star}$ & Stationary \\
\hline L & $-3.30^{\star \star}$ & Stationary \\
\hline
\end{tabular}

*implies stationary at 10\%, **implies stationary at 5\%, and *** implies stationary at 1\%

Five variables are integrated of order zero I $(0)$, that is, in levels, these are; area under maize production in the communal sector $(A P M N)$, capital $(K)$, rainfall $(R)$, producer price of maize $(P)$ and labour $(L)$ in agriculture.

Unit root test after first difference

\begin{tabular}{|c|c|c|}
\hline Variable & t-Phillips-Perron test & Conclusion \\
\hline$\Delta P C E$ & $-8.73^{* \star \star}$ & Stationary \\
\hline$\Delta$ FA & $-3.65^{\star \star}$ & Stationary \\
\hline$\Delta$ APCE & $-7.01^{\star \star \star}$ & Stationary \\
\hline$\Delta P M N$ & $-7.60^{\star \star \star}$ & Stationary \\
\hline
\end{tabular}

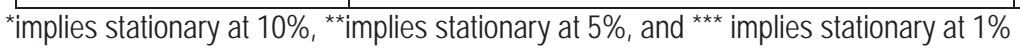

Food aid $(F A)$ area under maize cultivation in the commercial sector (APCE), commercial and communal sector maize production (PCE and PMN) are integrated of order one I (1). This confirms and strengthens the decision to use the Autoregressive Distributed Lag (ARDL) model for analyzing data at hand, since the data is not integrated of same order. The investigation concluded that the statistics are integrated of orders zero I(0) and one II(1). 


\subsection{Testing for Unique Co-integrating Vector - The Bounds Test Results}

Testing for unique co-integrating vector- F-test.

\begin{tabular}{|c|c|c|c|c|c|c|c|}
\hline & Dependent variable & Output & Labour & Capital & Area & Food aid & price \\
\hline Commercial Sector & F-statistic & $44.92^{\star \star}$ & 2.21 & $5.52^{\star *}$ & $12.64^{\star \star}$ & $5.01^{\star *}$ & $29.00^{\star \star}$ \\
\hline Communal Sector & F-statistic & $5.22^{\star \star}$ & 1.15 & $6.31^{\star \star}$ & $7.28^{\star *}$ & $5.20^{\star *}$ & $29.95^{\star \star}$ \\
\hline
\end{tabular}

*significant at $10 \%$, ** significant at $5 \%$, and ${ }^{* \star *}$ significant at $1 \%$

Tests for unique co-integrating vector and reverse causality for all endogenous variables were conducted. Rainfall is left out since it is not determined within the model and therefore, it is an exogenous variable. All endogenous variables exhibited a unique co-integrating vector except labour. Labour is not co-integrated with other variables in both the commercial and the communal sector. Availability of unique co-integrating vector in variables (PMN) and $(P C E)$ reveals that the model is correctly specified and there is a long run relationship between variables, hence the study proceeded with the other tests.

\subsection{Estimated Results for the Unrestricted (Vector) Error Correction Model Analysis}

\subsubsection{Commercial Sector Maize Production}

ARDL $(2,0,1,0,0,0,0)$ selected based on Schwarz Bayesian Criterion

\begin{tabular}{|c|c|}
\hline Regressor & coefficient \\
\hline$P C E(-1)$ & -0.13 \\
\hline$P C E(-2)$ & $-0.31^{\star \star \star}$ \\
\hline$A P C E$ & 4.87 *** \\
\hline$P$ & -0.039 \\
\hline$P(-1)$ & -0.10 \\
\hline$R$ & 5.16 * \\
\hline$F A$ & -0.80 \\
\hline$L$ & 0.013 \\
\hline$K$ & 0.0005 \\
\hline$C$ & -9.82 \\
\hline$R^{2}$ & 0.94 \\
\hline Adjusted $R^{2}$ & 0.92 \\
\hline F-stat & $44.92^{\star \star \star}$ \\
\hline$D W$-statistic & 2.13 \\
\hline
\end{tabular}

significant at $10 \%,{ }^{* *}$ significant at $5 \%$, and ${ }^{* * *}$ significant at $1 \%$

\begin{tabular}{|c|c|}
\multicolumn{2}{|c|}{ Diagnostic Tests } \\
\hline Lm test Statistics & LM version \\
\hline Serial correlation & $\chi^{2}(1)=1.0002[0.317]$ \\
\hline Functional form & $\chi^{2}(1)=0.058281[0.809]$ \\
\hline Normality & $\chi^{2}(2)=0.072603[0.964]$ \\
\hline Heteroscedasticity & $\chi^{2}(1)=0.25937[0.611]$ \\
\hline
\end{tabular}

Commercial maize production $\operatorname{ARDL}(2,0,1,0,0,0,0)$ is correctly specified with a very high $R^{2}$ and Adjusted $R^{2}$ of 0.94 and 0.92 respectively. This means that $92.48 \%$ of the variation in the dependent variable (PCE) is explained by the independent variables. The F-statistic is significant at $1 \%$ revealing the explanatory power of the model. Furthermore, there are low levels of auto-correlation since the DW test calculated is 2.13. The model also passed all four diagnostic tests, namely; the Breusch-Godfrey Serial correlation test, the Jacque-Bera Normality test, the Ramsey RESET Functional form test and the $A R C H$ Heteroscedasticity test with the following probability values $0.317,0.964,0.809$ and 0.611 respectively. 


\subsubsection{Communal Sector Maize Production}

$\operatorname{ARDL}(0,0,0,0,1,0,0)$ selected based on Schwarz Bayesian Criterion.

\begin{tabular}{|c|c|}
\hline Regressor & Coefficient \\
\hline$P$ & 0.026 \\
\hline$A P M N$ & -0.16 \\
\hline$R$ & $4.0^{* * *}$ \\
\hline$F A$ & $-1.34^{*}$ \\
\hline$F A(-1)$ & $1.80^{\star *}$ \\
\hline$L$ & $0.20^{*}$ \\
\hline$K$ & 0.0041 \\
\hline$C$ & $-2.96^{\star}$ \\
\hline$R^{2}$ & 0.66 \\
\hline Adjusted $R^{2}$ & 0.52 \\
\hline F-stat. & $5.22^{\star \star *}$ \\
\hline$D W$-statistic & 1.7 \\
\hline
\end{tabular}

*significant at $10 \%,{ }^{* *}$ significant at $5 \%$, and *** significant at $1 \%$

Diagnostic Tests

\begin{tabular}{|c|c|}
\hline & LM version \\
\hline Serial correlation & $\chi^{2}(1)=0.96[0.325]$ \\
\hline Functional form & $\chi^{2}(1)=2.46[0.135]$ \\
\hline Normality & $\chi^{2}(2)=0.08[0.956]$ \\
\hline Heteroscedasticity & $\chi^{2}(1)=0.43[0.510]$ \\
\hline
\end{tabular}

Communal maize production ARDL $(0,0,0,0,1,0,0)$ is correctly specified with $R^{2}$ and Adjusted $R^{2}$ of 0.66 and 0.53 respectively. The adjusted $R^{2}$ indicates that $52.82 \%$ of the variation in the dependant variable is explained by the independent variables. The $\mathrm{F}$ statistic is 5.22 with a probability value of 0.002 revealing the explanatory power of the model. There are low levels of auto correlation in our model since the DW test calculated is 1.7. The model also passed all four diagnostic tests, namely; the Breusch-Godfrey Serial correlation test, the Jacque-Bera Normality test, the Ramsey RESET Functional form test and the ARCH Heteroscedasticity test with the following probability values $0.325,0.956$, 0.135 and 0.510 respectively. The model does not suffer from structural breaks since it passed cumulative sum of squares (CUSUMQ) and cumulative sum of residual (CUSUM) test. These provide the required tests that render the model suitable and reliable in interpreting the data at hand.

\subsection{Estimated Long Run Coefficients}

\subsubsection{Commercial Sector Maize Production}

ARDL $(2,0,1,0,0,0,0)$ Approach selected based on Schwarz Bayesian criterion.

\begin{tabular}{|c|c|}
\hline Regressor & Coefficient \\
\hline APCE & $3.365^{\star \star \star}$ \\
\hline P & $-0.097^{\star}$ \\
\hline R & $8.07^{*}$ \\
\hline FA & $-0.55^{\star \star \star}$ \\
\hline L & 0.0095 \\
\hline K & 0.00035 \\
\hline C & -4.036 \\
\hline
\end{tabular}

*significant at $10 \%$, ** significant at $5 \%$, and *** significant at $1 \%$

The long-run model was estimated using ARDL $(2,0,1,0,0,0,0)$ specification model. Of the six variables that specified the model, capital $(K)$ and labour $(L)$ are insignificant but with expected positive coefficients in the long run commercial sector production function. Food aid ( $F A$ ) entered the model with an expected negative sign and is concluded to be significant at $5 \%$ LOS with a coefficient of -0.55 . An increase in food aid shipments negatively affected output in the commercial sector, which suggests that an increase in food aid could have discouraged commercial farmers from producing food crop, that 
is, maize. This tends to reveal that increase in food aid disturbed food markets in Zimbabwe, confirming claims that food aid has a disincentive effect on food crop production.

Commercial sector area under maize production (APCE) is found to be highly significant at $1 \%$ level of significance with an expected positive coefficient of 3.36. It therefore suggests that a decline in the area under maize production in the commercial sector has directly triggered a fall in output. The decline in commercial maize output in the commercial sector is linked to the land reform that started in the 1990s and was expedited in the year 2001 (Moyo, 2011). An increase in land under commercial food crop production, the model suggests, leads to an increase in food crop output.

In addition, rainfall $(R)$ entered the model with an expected positive coefficient of 8.07 and is significant at $10 \%$ level of significance. Increase in rainfall leads to an increase in output in the commercial sector (Muchapondwa, 2008). This affects all types of commercial farmers whether they produce using either irrigation schemes or the rain fed crop since drought results in a reduction in water essential for crop production. These findings confirm results concluded by other researchers.

Commercial farmers produce commodities with a profit motive determined by prices offered in the market. The variable price $(P)$ entered the model with an unexpected negative coefficient of -0.09 and it is significant at $10 \%$ level of significance. An explanation to the negative coefficient on producer prices could be the spiraling inflation that has characterized the last part of the period under study in relation to the declining level of maize output in the commercial sector. The sudden decline in maize output seems to be fairly explained by, among other things, poor producer prices offered by Government through the Grain marketing Board (GMB). During the period under study, Government continually pursued a policy where it set a ceiling for maize producer prices that were not necessarily market determined and could go for a long period without being reviewed.

Other factors that could have affected the model are captured in the constant $(C)$. The factors were concluded to be insignificant. I.

\subsubsection{Communal Sector Maize Production}

$\operatorname{ARDL}(0,0,0,0,1,0,0)$ selected based on Schwarz Bayesian Criterion.

\begin{tabular}{|c|c|}
\hline Regressor & Coefficient \\
\hline$P$ & 0.026 \\
\hline$A P M N$ & -0.16 \\
\hline$R$ & 4.0 *** \\
\hline$F A$ & 0.45 \\
\hline$L$ & $0.20^{*}$ \\
\hline$K$ & 0.004 \\
\hline$C$ & $-2.96^{*}$ \\
\hline
\end{tabular}

The long-run communal agriculture sector model is estimated using ARDL $(0,0,0,0,1,0,0)$ specification model in the table above. Rainfall is concluded to be significant at $1 \%$ level of significance with an expected positive coefficient of 4.0. This comes as no surprise as droughts severely affect food crop production in communal areas because they are associated with rain fed crop production. This seems to propose that communal farmers improve their output if they could control the rainfall variable and other technological endowments as well as entitlements (Dreze et al., 1991). Food aid entered the model with an insignificant positive coefficient. Possible reasons could be that food aid could have been targeted and communal maize producers are mainly peasant farmers. The result reveals that peasant farmers' food crop production is not affected by food aid shipments in an economy. This could be due to the fact that production of food crop is not profit driven, but it is basically subsistence. In addition, prices are found to be insignificant in the model, although the coefficient is positive as expected by theory.

Communal sector area under maize cultivation (APMN) is not significant and has an unexpected negative coefficient of -0.31 . A positive expected coefficient 0.20 of labour and a probability value of 0.071 suggest that labour is significant in the communal areas at $10 \%$ level of significance. An increase in labour in the communal areas stimulates production of food crop, maize. Other factors that could not be captured in the model that could have affected the model represented in the constant $(C)$ were found to be significant at $10 \%$. The factors have a negative coefficient of -2.96 , reflecting that increase in the factors captured in $(C)$ would result in decline in maize output. 


\subsection{Short Run Analysis. Error Correction representation for the selected ARDL Model}

\subsubsection{Commercial Sector Maize Production}

$\operatorname{ARDL}(2,0,1,0,0,0,0)$ selected based on Schwarz Bayesian Criterion.

\begin{tabular}{|c|c|}
\hline Regressor & Coefficient \\
\hline dPCE1 & $0.31^{\text {** }}$ \\
\hline dAPCE & $4.87^{* \star \star}$ \\
\hline$d P$ & -0.039 \\
\hline$d R$ & 5.16 *** \\
\hline$d F A$ & -0.80 ** \\
\hline$d L$ & 0.013 \\
\hline$d K$ & 0.0005 \\
\hline$d C$ & -9.82 \\
\hline$E C M(-1)$ & -0.44 *** \\
\hline$R^{2}$ & 0.93 \\
\hline Adjusted $R^{2}$ & 0.89 \\
\hline F-stat. & $29.21^{\star \star \star}$ \\
\hline$D W$-statistic & 2.13 \\
\hline
\end{tabular}

*significant at 10\%, ** significant at 5\%, and *** significant at 1\%

$E C M=P C E-3.31^{*} \mathrm{APC}+0.039^{*} \mathrm{P}-8.07{ }^{*} \mathrm{R}+0.80^{*} \mathrm{FA}-0.013^{*} \mathrm{~L}-0.0005^{*} \mathrm{~K}+4.036^{*} \mathrm{C}$

The short run model analysis in commercial agricultural sector shows that the variable under spotlight food aid is significant at $5 \%$ level of significance with a negative coefficient of -0.80 . Food aid shipped in the country in the short run would affect food crop output in the commercial sector. Output (dPCE1) in the preceding year significantly affects current output at $1 \%$ level of significance and has a positive coefficient of 0.31 . If output in the previous period is increasing, it is expected that output in the next period follows suit.

Area under maize cultivation (APCE) in the commercial sector has been found to be significant at $1 \%$ level of significance with an expected coefficient of 4.87 in the short run. If more land is made available to commercial farmers in the current period, that is, used for maize production, all things being equal, the output should increase. In the short run producer prices of maize entered the model with a negative sign of -0.039 and are insignificant. Rainfall is critical in ensuring output in the current period. It is significant at $5 \%$ level of significance and has an expected positive coefficient of 5.16 .

The constant $(C)$ that tends to capture those variables that failed to appear in the model is not significant. Capital $(K)$ entered the model with an expected positive sign, but is insignificant. Labour is also found to be insignificant in the commercial sector maize production, although the sign of the coefficient is positive as expected. This could be due to the advent of new technology that is rampant in modern agriculture that has tended to substitute labour by capital. This could have been caused by the choice of our proxy for labour included in the model.

\subsubsection{Communal sector maize production.}

$\operatorname{ARDL}(0,0,0,0,1,0,0)$ selected based on Schwarz Bayesian Criterion.

\begin{tabular}{|c|c|}
\hline Regressor & Coefficient \\
\hline$d P$ & 0.026 \\
\hline$d A P M N$ & -0.16 \\
\hline$d R$ & $4.0^{* \star *}$ \\
\hline$d F A$ & $-1.34^{\star}$ \\
\hline$d L$ & $0.20^{*}$ \\
\hline$d K$ & 0.0041 \\
\hline$d C$ & $-2.96^{*}$ \\
\hline$E C M(-1)$ & $-0.89^{* * \star}$ \\
\hline$R^{2}$ & 0.82 \\
\hline Adjusted $R^{2}$ & 0.75 \\
\hline F-stat & $12.76^{\star \star \star}$ \\
\hline DW-statistic & 1.7 \\
\hline
\end{tabular}

${ }^{*}$ significant at $10 \%,{ }^{* *}$ significant at $5 \%$, and ${ }^{* \star *}$ significant at $1 \%$ 
$E C M=P M N-0.026^{\star} \mathrm{P}+0.16^{\star} \mathrm{A}-4.0^{*} \mathrm{R}-0.45^{\star} \mathrm{FA}-0.20^{\star} \mathrm{L}-0.0041^{\star} \mathrm{K}+2.96^{*} \mathrm{C}$

The short run responses of communal sector production to other variable in the model are presented in the table above. Food aid is found to be weakly significant at $10 \%$, with a negative coefficient of -1.34 , suggesting that food aid may weakly affect output in the communal sector in the short run. It is therefore concluded that food aid could have some weakly defined disincentive effects in communal maize production in the short run. A major significant variable in short run production is found to be rainfall with positive coefficient of 4.0 and a level of significance of $1 \%$. Availing water for cropping to communal farmers instantaneously boosts their food crop output.

Labour in agriculture $(L)$ is significant at $10 \%$ level of significance and has an expected positive coefficient of 0.21 . In the short run, if labour increases in the rural areas, the food crop output should increase. Other factors that were not specified in the model captured in $(C)$ were found to be significant at $10 \%$ level of significance and had a coefficient -2.96 . An increase in the factors captured in $(C)$ will reduce maize output in the communal sector. Producer prices $(P)$ and communal sector area under maize production $(A P M N)$ are concluded to be insignificant. The error correction term (ECT) is concluded to be significant at 1\% LOS and a very high level of adjustment to previous period disturbances of $89.64 \%$. This suggests that $89.64 \%$ of disturbances in the previous period can be corrected in the current period.

\section{Conclusions and Recommendations}

The study finds that there are disincentive effects of food aid on food crop production in the commercial maize production sector in the short run as well as the long run. However, what is not clear is the transmission mechanism that takes effect when there is an increase of food aid in the economy. Furthermore, no evidence of disincentive effects of food aid on food crop production is concluded in the communal sector maize production in the ARDL short run model. The ARDL long run model for the communal sector exhibited no evidence of disincentive effects of food aid on food crop production. This variation in the findings could best be explained through production motives of the two agricultural sectors in Zimbabwe. Commercial maize farmers engage in production with a profit motive whereas communal farmers' main thrust to production is subsistence. The study therefore concludes that food aid has disincentive effects on food crops production in commercial maize production sector.

During times when food crisis is affecting particular areas in the country and some areas may have sufficient food, donor agents should be encouraged to source food in the local market. This stabilizes prices in the domestic market and ensures increased future food production considering that buying from local farmers has a tendency to economically empower and build revenue for domestic farmers. This can only be achieved when Government relieves the Grain Marketing Board of its monopoly on purchasing of grain in the domestic market as is proposed by the Ministry of Finance (Government of Zimbabwe National Budget, 2009).

Trade of food crops should remain liberalized to ensure that producers realize a return that is in tandem with world market price. The government should also consider a producer price subsidy to maize farmers in years when the world price will be below the break-even point. In addition, to cushion farmers from production costs, government should consider a blanket subsidy on agricultural inputs. This is necessitated by the fact that agricultural production expenditures in Zimbabwe may not necessarily be equal to those faced by the developed world. The move will go a long way in providing incentives to farmers, which encourages continued food crop production.

Food aid agents should be monitored to ensure that they provide mainly targeted food aid. The food shipments should be properly targeted such that they do not reach the intended beneficiaries at the wrong time when food crisis is over or are given to self-sufficient recipients who end up selling the food aid in the local market.

Although food aid has played a vital role in averting famine and starvation, government should strive to ensure that the economy ceases to depend heavily on food aid as this is not sustainable. This can only be possible by ensuring that the agricultural sectors produce food in excess. Government should also be in a position to build food reserves so that in times food shortages, the food coffers can be used to avert crisis. An area that requires further investigation is the transmission mechanism that leads to a reduction in food crop production in the commercial agricultural sector.

\section{References}

Abdulai, A., Barrett, C.B., Hoddinott, J., 2005. Does food aid< i> Really</i> have disincentive effects? New evidence from sub-Saharan Africa. World Dev. 33, 1689-1704.

Barrett, C.B., 1998. Food aid: is it development assistance, trade promotion, both, or neither? Am. J. Agric. Econ. 566-571.

Barrett, C.B., 2001. Does food aid stabilize food availability? Econ. Dev. Cult. Change 49, 335-349.

Barrett, C.B., 2002. Food aid and commercial international food trade. Organ. Econ. Coop. Dev. OECD Trade Mark. Div. Backgr. Pap. 
Paris.

Barrett, C.B., 2006. Food aid's intended and unintended consequences. Backgr. Pap. FAO State Food Agric. 2-3.

Barrett, C.B., Maxwell, D.G., 2006. Towards a global food aid compact. Food Policy 31, 105-118.

Bezuneh, M., Deaton, B., 1997. Food aid impacts on safety nets: theory and evidence: a conceptual perspective on safety nets. Am. J. Agric. Econ. 672-677.

Bezuneh, M., Deaton, B., Zuhair, S., 2003. Food aid disincentives: the Tunisian experience. Rev. Dev. Econ. 7, 609-621.

Brüderl, J., 2003. Applied regression analysis using stata. Skriptum Zur Vorles. Im Frühjahr.

Chaumba, J., Scoones, I., Wolmer, W., 2003. From jambanja to planning: the reassertion of technocracy in land reform in south-eastern Zimbabwe? J. Mod. Afr. Stud. 41, 533-554.

Clay, D.C., Molla, D., Habtewold, D., 1999. Food aid targeting in Ethiopia: A study of who needs it and who gets it. Food Policy 24, 391409.

Dhemba, J., Gumbo, P., Nyamusara, J., 2002. Social security in Zimbabwe: Phase II: Zunde raMambo and burial societies. J. Soc. Dev. Afr. 17.

Dickey, D.A., Fuller, W.A., 1981. Likelihood ratio statistics for autoregressive time series with a unit root. Econom. J. Econom. Soc. $1057-1072$.

Dreze, J., Sen, A.K., others, 1991. Hunger and public action. Oxford Clarendon.

Ellis, F., 1992. Agricultural policies in developing countries. Cambridge University Press.

Enders, W., 2008. Applied econometric time series. John Wiley \& Sons.

Ghatak, S., 2003. Introduction to development economics. Psychology Press.

Hoogeveen, J.G., Kinsey, B.H., 2001. Land reform, growth and equity: Emerging evidence from Zimbabwe's resettlement programme-A sequel. J. South. Afr. Stud. 27, 127-136.

Isenman, P.J., Singer, H.W., 1977. Food aid: Disincentive effects and their policy implications. Econ. Dev. Cult. Change 205-237.

Lavy, V., 1990. Does food aid depress food production. Disincentive Dilemma Afr. Context Doc. Trav.

Levinsohn, J., McMillan, M., 2007. Does food aid harm the poor? Household evidence from Ethiopia, in: Globalization and Poverty. University of Chicago Press, pp. 561-598.

Morduch, J., Sharma, M., 2002. Strengthening public safety nets from the bottom up. Dev. Policy Rev. 20, 569-588.

Moyo, S., 2000. Land reform under structural adjustment in Zimbabwe: land use change in the Mashonaland provinces. Nordic Africa Institute.

Moyo, S., 2011. Changing agrarian relations after redistributive land reform in Zimbabwe. J. Peasant Stud. 38, 939-966.

Muchapondwa, E., 2008. Estimation of the aggregate agricultural supply response in Zimbabwe: The ARDL approach to cointegration. Sch. Econ. Univ. Capetown Work. Pap. 1-13.

Palmer, R., 1990. Land reform in Zimbabwe, 1980-1990. Afr. Aff. 163-181.

Sachikonye, L.M., 2003a. From "growth with equity"to "fast-track"reform: Zimbabwe's land question. Rev. Afr. Polit. Econ. 30, $227-240$.

Sachikonye, L.M., 2003b. The situation of commercial farm workers after land reform in Zimbabwe. Rep. FCTZ.

Snowdon, B., Vane, H.R., 2005. Modern macroeconomics: its origins, development and current state. Edward Elgar Publishing.

Srinivasan, T.N., 1989. Food aid: a cause of development failure or an instrument for success? World Bank Econ. Rev. 3, 39-65.

Tadesse, G., Shively, G., 2009. Food aid, food prices, and producer disincentives in Ethiopia. Am. J. Agric. Econ. 91, 942-955.

Government of Zimbabwe (2008). The Agriculture Sector of Zimbabwe Statistical Bulletin 2008. Harare. Government Printers 